\title{
Higher Education: A Catalyst For Capacity Building, Economic Growth And National Development In Africa
}

\author{
M. O. B. MOHAMMED (Ph.D) \\ Department of Educational Management, Faculty of Education \\ Lagos State University, Ojo. Lagos State, Nigeria. \\ L. 0. Yahya (MRS) \\ Department Of Educational Management, Faculty Of Education \\ Lagos State University, Ojo. Lagos State, Nigeria. \\ M. D. Rufai \\ Department Of Educational Management, Faculty Of Education \\ Lagos State University, Ojo. Lagos State, Nigeria.
}

\begin{abstract}
There is increasing evidence that high levels of education in general, and of tertiary education in particular, are essential for the design and productive use of new technologies, while they also provide the foundations for any nation's innovative capacity. Investment in higher education per se is a necessary but not a sufficient condition for development. As important as the investment made in higher education is, attention must be paid to the efficiency and effectiveness of that investment which includes ensuring that there are appropriate linkages with the labour market needs of the economy. As the race towards rapid and sustained improvement in knowledge and human resources gathers momentum, Nigeria and Africa must not be found wanting. Rather, formulation and implementation of a long-term growth strategy geared towards the development of human capital will address the current imbalances in the system and drive economic growth and national development. This paper reviews the impact of higher education on capacity building, economic growth and national development.
\end{abstract}

\section{BACKGROUND}

Education is widely accepted as a leading instrument for promoting economic growth. For African, where growth is essential if the continent is to climb out of poverty. Education is particularly important for several decades, Africa countries and their development partners have place great emphasis on primary and more recently, secondary education. But they have neglected tertiary education as a means to improve economic growth and mitigate poverty. The Dakar submits on "Education for All" in 2000, for examples, advocated only for primary education as a driver of social welfare. It left tertiary education in the background.

Tilqak (2003) assert that part of the reason for the extension of higher education from development initiatives lies in the shortage of empirical. Evidence that it affects economic growth and poverty reduction. Bloom, Hartley and Rosovsky (2004) suggests higher education is both as a result and a determinant of income, and can produce public and private benefits.

The necessity for capacity building cannot be overemphasized. There is a strong dialectical relationship not only between geographical, anthropoid and abstract sources of wealth generation but eually a strong relationship between intellectual poverty, research and development activities carried out in the universities. 
Kofi (2000) argued that the university must become a primary tool for African's development in the new century. University can help develop African expertise; they can enhance the analysis of African problems; strengthen domestic institutions; serve as a model environment for the practice of good governance conflict resolution and respect for human rights, and enable African academics to play an active part in the global community of scholars.

This paper is divided into five sections, section one is the introductory part, section two take an overview of conceptual link from higher education capacity, building to economic growth while section three examined constraints to higher education in Africa. Section four focused on recommendations and finally section five formed the concluding part.

\section{Conceptual Link From Higher Educaton To Economic Growth}

Until the mid-1990s the role of higher education in Africa's development was something of an anomaly, with the majority of education development projects focused on the level of primary or secondary schooling. International donors and partners regarded universities, for the most part, as institutional enclaves without deep penetration into the development needs of African communities. Amongst other things, this view was promoted by the World Bank for many years. This one-dimensional strategy led to development policies that had negative consequences for African societies and the potential for the sustainable development of their economies.

Neglect of higher education led to the establishment of research centres, medical schools, agricultural centres, telecommunication and technological development centres, business training centres, vocational and skill schools and other areas in tertiary education sector, which are critical to the development of African societies and their economies.

Three fundamentally different positions with respect to higher education's role in development initiative can be distilled from the literature. The first could be called "higher education as luxury ancillary", from this perspective higher education is a sector that every country should have, but it is a "luxury sector" compared, for example, to primary education and its rate of return or infrastructure development which provides more direct poverty relief than education or health (World Bank, 2004). This approach is not only supported by international policy agencies, but, also by many governments in Africa.

The second approach acknowledges a role for higher education in national development, but conceptualizes it as "a producer of appropriately skilled professionals and applied knowledge" or in the words of professor Ndebele " a service producing educated workers, rather than a strategic value adding asset".

The third position locates higher education as the "engine of development in the new knowledge economy".

According to this view, the new mode of economic production are increasingly dependent in knowledge and information technology. Knowledge and "informationalism" have become central to development in the global economy. The availability and use of information and communication technology is a pre-requisite for economic and social development.

A recent World Bank calculation shows that the knowledge sector adds more value to a product than the business process (serageldin, 2000). So, "if knowledge is the electricity of the 
new information international economy, then institutions of higher education are the power source on which a new development process must rely" (castells, 2001).

Signs of progress for higher education are appearing in sub-saharan Africa. The international development community has begun to realize the importance of advanced schooling, while some African countries have introduced innovative policies to strengthen tertiary education systems.

From the diagram below, higher education can lead to economic growth through both public and private channels. The private benefits for individuals are well established, and include better employment prospects, higher salaries, and a greater ability to save the invest. These benefits may result in better health and improved quality of life, thus setting off a virtuous spiral in which life expectancy improvements enable individuals to work more productively over a longer time further boosting life time earnings.

Public benefits are less widely recognized which explains many governments neglect of tertiary schooling as a vehicle for public investment. But individual gains can also benefits society as a whole. Higher earnings for well-educated individuals raise tax revenues for governments and ease demands on state finances. They also translate into greater consumption, which benefits producers from all educational backgrounds.

In a knowledge economy, tertiary education can help economies keep up or catch up with more technologically advanced societies. Higher education graduates are likely to be more aware of and better able to use new technologies. They are also more likely to develop new tools and skills themselves.

Their knowledge can also improve the skills and understanding of non-graduate co-workers, while the greater confidence and know-how inculcated by advanced schooling may generate entrepreneurship, with positive effects on job creation. 


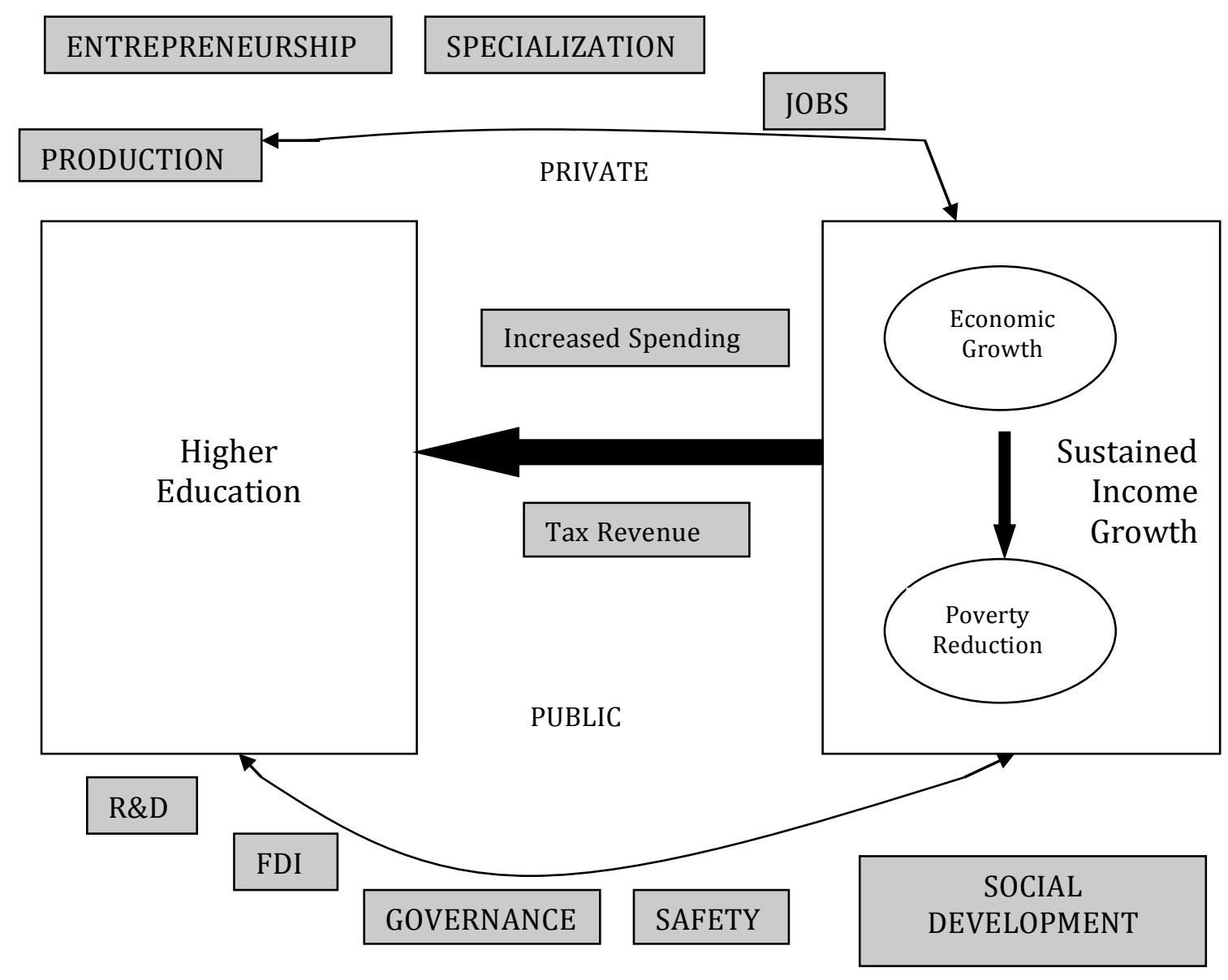

\section{Diagrammatical Representation Of Higher Education And Economic Growth Source: WordBank.org/etools/docs/library.pdf.}

Tertiary schooling can also have less direct benefits for economies. By producing well-trained teachers, it can enhance the quality of primary and secondary education systems and give secondary graduates greater opportunities for economic advancement. By training physicians and other health workers, it can improve a society's health, raising productivity at work. And by nurturing governance and leadership skills, it can provide countries with the talented individuals needed to establish a policy environment favourable to growth. Setting up robust and fair legal and political institutions and making them a part of county's fabric, and developing a culture of job and business creation, for example, call for advanced knowledge and decision-making skills. Addressing environmental problems and improving security against internal and external threats also place a premium on the skills that advanced education is best place to deliver.

Although none of these outcomes is inevitable, the framework presented in the diagram above does suggest many possible routes through which higher education can benefit economies.

A series of studies have taken into account the broader impacts of higher education.

Bloom, Hartley and Rosovsky (2004) showed that college graduates in the United States of America had higher productivity and earnings thorn non-graduates. Moreover, workers in the 
United States of America where the proportion of college graduates in high earn significantly more thorn those states with few graduates.

The same study shows a positive correlation between higher education and entrepreneurship. It also showed that individuals with higher educational levels were more likely to engage entrepreneurial activity, and more educated entrepreneur's greater larger numbers of jobs than less educated entrepreneurs.

Lederman and Maloney (2003) conducted a cross-country regression analysis that showed that the rate of return on Research and Development was 78 percent which is another channel for improvement which can boost economic growth and productivity.

Lin (2004) in a study conducted in Taiwan showed that higher education played a strong role in the country's economic growth. It found that a 1 percent rise in higher education stock (as defined by those who had completed higher education, including junior college, college, university, or graduate school) led to a 0.35 percent increase in industrial output, and that a 1 percent increase in the number of graduates from engineering or natural sciences led to a 0.15 percent increase in agricultural output.

This work examined the effects of concentration in different disciplines and concluded that study of the natural Science and engineering had the largest effect on output.

\section{Constraints To Highereducation In Africa}

If Africa is to move beyond poverty relief and crisis management, then what is missing from underpinning many of the laudable programmes is a more systematic knowledge and expertise base about higher education in Africa. Regarding the study of higher education in Africa various developmental constraints can be identified among which are:

The fragmented nature of higher education as a field of study; inconsistent and fragmented funding; and uneven distribution of knowledge of the field.

Higher education is not a discipline, but an interdisciplinary, applied field without commonly accepted methodologies, or even general agreement on what counts as knowledge. Compounding this problem, research is all too often driven by political or funder agendas. Between the latest reform initiative of government, and the associated sudden interest, or lack thereof, from funding agencies, research often becomes little more than consultancy, and thus becomes little more than another competing and voice in the reform market place. Within such an environment, the building of a systematic, programmatic knowledge base in the field of higher education remains unlikely.

The knowledge, expertise and skills needed for building policy for developing leadership and management capacity in higher education at all relevant levels and for developing the capacity to study higher education, are unequally distributed.

It should be noted however that higher education will not make a difference in Africa if other barriers to development play a determinative and negative role. Without sensible maro economic management, new graduates will be much less likely to find productive work. Good governance is another sine qua non. Openness to trade with provisions to ensure that Africa actually benefits from such openness and with increased cooperation from developed countries- is likely to be key. Dept relief, for some African countries, may also allow governments to begin programmes that take better advantage of well-educated workers. 


\section{RECOMMENDATIONS}

More systematic knowledge about African higher education is not only necessary to improve higher education delivery, but also to engage in a more informed manner with funders, and for development agencies to make better investment and capacity building choices.

The 2004 Annual Review of Development Effectiveness asserts that "high quality analytical work, with sound diagnosis of and recommendations for institutional and sectorial reforms, has a big payoff".

To ensure higher education leads to capacity building, economic growth and national development. The following steps must be taken by the government:

* Produce a more systematic research - informed knowledge base about higher education.

* Train researchers who can advance higher education as a field of study;

* Facilitate better links/interactions between higher education researchers and policy makers, institutional leaders and other higher education stakeholders

What is needed is a focused effort to develop an African co-operation structure on higher education that would allow for relevant graduate programmes, research activities and capacity building through effective national and international networking.

Higher education creates the potential, but government and private sectors must seize the opportunities.

\section{CONCLUSION}

Joking with education is laughter into penury and poverty. Higher education may improve technological catch-up and in doing so, maximize Africa's potential to achieve its greatest possible economic growth given current constraints. Investing in tertiary education in Africa may accelerate technological diffusion, which would decrease knowledge gaps and help reduce poverty in the region.

Government must invest more in higher education. It should be stressed that an educated populace is not only aware but will be automatically productive. The quality of education must be improved because it is only educated people who will move the economy forward and who will improve on welfare. No long term economic vision plan will succeed without the contribution of the citizens.

Higher education may create greater tax revenue, increase savings and investment, and lead to a more entrepreneurial and civic society. It can also improve a nation's health, contribute to reduced population growth, improve technology and strengthen governance. Many observers attribute India's leap onto the world economic stage as stemming from its decades-long successful efforts to provide high quality, technically oriented tertiary education to a significant number of its citizens.

\section{References}

Bloom, D.E; Hartley, M; and RosovSky, H.M(2004) Social benefits of higher education. Available at www.ifhe.net/resources/social-benefits -of higher-edu.ppt.

Bloom, D.E; Canning, D; and Servilla, J. (2004). The Effects of Health on Economic Growth: A Production Function approach. World Development. 32(1):1-13 
Ikharehon, J.I. (2007). Capacity Building for National Sustainable Development: The Nigerian experience. Journal of social sciences 15(1), 25-29

Lederman,D; and Maloney, W.F (2003) “Research and Development” Policy Research Working Paper No. 3024 World Bank.

Lin, T.C. (2004). The Role of Higher Education in economic Development: An Empirical Study of Taiwan case. Journal of Asian economics. 15(2), 355-371.

Tilak, J.B (2003) Higher Education and Development Retrieved 3rd March 2013 from www.mec.gov.br/univxxi/pdf/joundhyal.pdf

United Nations Development Programme (2005). Human Development Report, UNDP New York: Oxford university Press.

Wikibooks (2013) University Education. Retrieved 2nd March 2013 from http://www/en.wikibooks.org/wiki/university education

Wikipedia (2013) Human Capital Theory. Retrieved 2nd March 2013 from http:www/en.wikipedia.org/human capital theory

Wikipedia (2013) Capacity Building. Retrieved 1st March 2013 from http:www/en.wikipedia.org/capacity building. 